Corresponding Authors: Berjudul:

\title{
The Role of Top Management Commitment to Enhancing the Competitive Advantage Through ERP Integration and Purchasing Strategy
}

\author{
Paper Submission
}

Your Submission: IJEIS-00868 External Inbox $x$

Madjid Tavana <tavana@lasalle.edu>

巴e Wed, Jul 17, 2019, 9:11 AM \& $\leftrightarrow$ :

to me, hotlan.siagian@petra.ac. id, f.jile@ecu.edu.au .

Manuscript Number: IJEIS-00868

Manuscript Title: The Role of Top Management Commitment to Enhancing the Competitive Advantage Through ERP Integration and Purchasing Strategy

Dear author(s)

I am pleased to inform you that your paper has been accepted for publication in the International Journal of Enterprise Information Systems (IJEIS) subject to the following minor revision(s)

- Your literature review is insufficient and outdated. You need to expand your literature review. A typical academic paper should have around 40-50 references. To this end, your manuscript MUST include at least 10 additional relevant references published in academic journals in 2019. You MAY also want to look at the previously published papers in our journal to strongly couple your paper with the RELEVANT existing works published in our Journal. Please make sure to highlight the new references in your revised manuscript and in your references list so the reviewers and the editor can clearly see your new references.

Please return your revised manuscript along with the following by $\underline{\mathbf{J u l y}} \underline{\mathbf{2 8}}, \underline{\mathbf{2 0 1 9}}$ directly to me through email at tavana@lasalle.edu. Do not submit your revised manuscript through the online submission system - everything MUST be submitted directly to me through email:

1. The complete final manuscript in Microsoft Word format with complete postal and email addresses of EACH author on the cover page and a short biography (100-150 words) for each author placed right after the title page and before your abstract.

2. Signed Author's Warranty and Transfer of Copyright Agreement (MUST BE in PDF format ONLY!). The blank form is attached. The corresponding author can sign the copyright agreement on behalf of all authors.

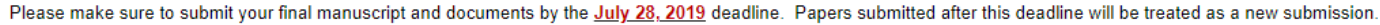

Best regards,

Madjid

Madjid Tavana, Ph.D

Professor and Chai

Business Systems \& Analytics Department

La Salle University, Philadelphia, PA 19141, USA

Honorary Professor

Business Information Systems Department

Decision Support \& Operations Research Lab

University of Paderborn, D-33098 Paderborn, Germany

Editor-in-Chief

International Journal of Applied Decision Sciences

International Journal of Management and Decision Making

International Journal of Communication Networks and Distributed Systems

International Journal of Knowledge Engineering and Data Mining

International Journal of Strategic Decision Sciences

International Journal of Enterprise Information Systems

Phone: +1.215.951.1129; Fax: +1.267.295.2854; Skype: madjidtavana 
Z Zeplin Jiwa Husada Tarigan <zeplin@petra.ac.id $>$

Dear Professor Madjid Tavana, Ph.D

We are pleased and thank you for your email regarding your acceptance to our article with the title: The role of top management commitment to enhancing the competitive Advantage through ERP integration and Purchasing Strategy

We are working hard on revising the manuscript based on your request on your email and expecting to submit the revised manuscript by yesterday Friday. However, we have not finished the revision yet and failed to submit. The pending item is that we have not found yet enough number of articles (minimum of ten articles). We are trying to find it as many as possible from IJEIS.

Remembering the two days of the weekend and 28 July is Sunday, we are worried that we can not submit the revised paper on Sunday, 28 July 2019 as the deadline.

For that condition above, could you please consider to give us a two days extension of the deadline and we will submit the revised paper by Wednesday, 31 July 2019 . We are very interested and motivated to have our article published on your IJEIS.

Thank you very much for your kind consideration and looking forward to hearing good news from you.

Sincerely yours

On behalf of the authors

Z Zeplin Jiwa Husada Tarigan <zeplin@petra.ac.id $>$

to tavana, Phd

Dear Professor Madjid Tavana, Ph.D

Thank you for your response.

Fortunately, we finally finished the revision of our paper following your request.

Please find attached the revised manuscript and signed IGI Publication Agreement and please notice as follows:

1. We have added 14 new references to the previous paper, and there are now 50 references in total. New references are written in red color in the text and references list as well.

2. We have checked in the IJEIS journal, and we found many articles are relevant to our article. We have downloaded online three articles plus one an open-access article. Hence there is four articles from IJEIS have been cited on our paper.

3. We have also added a short biography of the three authors. It is located on the title page and just before the abstract as your request.

4. Mr.Zeplin has signed the publication agreement as a corresponding author. However, the agreement is written by handwriting because we have a small problem with our printer just before printing the agreement. If you need a printed one, we can provide it by tomorrow.

We hope this revised manuscript and signed IGI publication have complied with your requirement.

Once again, thank you for your consideration to accept our paper and look forward to hearing good news from you.

Best regards

On behalf of the authors 


\title{
The Role of Top Management Commitment to Enhancing the Competitive Advantage Through ERP Integration and Purchasing Strategy
}

\author{
Zeplin Jiwa Husada Tarigan ${ }^{1}$, Hotlan Siagian ${ }^{2}$, Ferry Jie ${ }^{3}$ \\ ${ }^{1,2}$ Faculty of Business and Economics, Petra Christian University \\ ${ }^{3}$ Edith Cowan University, School of Business and Law \\ Email.1zeplin@petra.ac.id; ${ }^{2}$ hotlan.siagian@petra.ac.id; ${ }^{3}$ f.jie@ecu.edu.au
}

Authors short biography

Zeplin Jiwa Husada Tarigan, born in 1974, obtained his Bachelor degree in Electric and Telecommunication engineering, and Master's degree in Industrial Management from Sepuluh Nopember Institute of Technology. He obtained his Doctorate from the University of Brawijaya, Malang, Indonesia. He has experience as a manager in PPIC and BPO PP SAP R/3 in some manufacturing industries. At the moment, he is a full-time faculty member at Petra Christian University, teaching in the Program Magister Management or Master's program. His research interests are ERP and operation management

\begin{abstract}
Hotlan Siagian, born in 1963, obtained his Bachelor degree in Mechanical Engineering from USU Medan, and Master's degree in aeronautic production management from ENSICA Toulouse, France. He completed his Doctoral of Business Management in 2014 from Padjadjaran University in Bandung, Indonesia. He worked for 20 years in Domestic Airlines as executive management. At the moment, he is a full-time faculty member ass Assistant professor and lecturer at the Master Management department at Petra Christian University, Surabaya, Indonesia. He got a strong research background and has published several papers on supply chain management, strategic management, and business process re-engineering. He is an Indonesian citizen and a fellow of the Indonesian supply chain and logistics association.

Prof Ferry Jie, Ph.D. is the Associate Professor in Supply Chain and Logistics Management, in the School of Business and Law, Commerce Discipline. Also, Ferry is a Deputy Director, Centre for Innovative Practice. Prof Ferry Jie, P.hd: From 2013 to 2018, Dr. Jie has published 33 refereed journal articles (including 8 (eight) articles in A Ranked Journal - ABDC Journal Lists) and 20 refereed conference papers. Furthermore, Dr. Jie has received research grants/awards to the amount of $\$ 1,304,604.07$ between 2010 and 2018.
\end{abstract}

\begin{abstract}
The role of the top management commitment in enhancing the competitive advantage through ERP integration and the purchasing strategy. Data were collected using questionnaires from 49 manufacturing companies domiciled in the region of East Java, Indonesia. PLS technique was used to analyze the data. The result of the study indicated that; top management commitment influences ERP integration and the purchasing strategy, top management commitment influences the competitive advantage, ERP integration affects the purchasing strategy, ERP integration and purchasing strategy influences the competitive advantage. One of the most exciting findings revealed that ERP integration and purchasing strategy mediated the influence of top management commitment on the competitive advantage. Top management influence, directly and indirectly, the competitive advantage. This result provides the managerial implication that the management needs to establish an ERP integration and define a proper purchasing strategy in enhancing the competitive advantage of the manufacturing company.
\end{abstract}

\section{KEYWORDS}

Top management commitment, ERP integration, purchasing strategy, competitive advantage.

\section{INTRODUCTION}

In the new global economy, many countries have established communities within regional and world trading cooperation in different geographical areas and the industrial sector (Sweeney et al., 2018). The 
company has no choice rather than preparing to face international competition, which intensifies as a world and regional trading community established. Nevertheless, this trading community has emerged a new opportunity and threat as well for the companies domiciled in the country member of the community (Silvestre et al., 2018). Among the opportunities is access into the broader potential market for the finished product and the sourcing of raw material from overseas. Similarly, this situation has also emerged new threats in the form of intensified competition between the product competitive dimensions such as cost, delivery, and responsiveness. This constraint has exposed the company to the risk of higher cost, longer lead time, and less responsiveness The need for supply chain management practices become unavoidable as the network of the supply chain become more complex either for the sourcing of raw material from overseas or the distribution of the finished product abroad (Sweeney et al., 2018; Li et al., 2006). The company should anticipate these potential risks and if possible (Sauer \& Seuring, 2017), create a competitive advantage in respect of cost, delivery, flexibility, quality, responsiveness, and inventory system (Li et al., 2006).

About this condition, recently, researchers have shown an increasing interest in the field of supply chain management in pursuit of how to enhance the competitive advantage and firm performance from supply chain integration (Huo et al., 2014). Research by Nikookar et al., (2010) suggested that the implementation of enterprise resources planning (ERP) enhances the competitiveness of the company because ERP enables the company to retrieve appropriate data in the manner of real-time and accurate which, subsequently, facilitates the achievement in the costs reduction, right decision making, better customer response, and the improvement process. The implementation of ERP provides the ability to connect all departments in the company resulting in more efficient administration, coordination effectiveness and more accurate data in controlling the company's inventory (Shee et al., 2018). ERP implementation allows the company to reduce the cost of goods or services without sacrificing the quality level (Chugh et al., 2017). Many enterprises have adopted the ERP system into their operational process in various process or modules such as accounting, organizational control, management system, and operational, and cost visibility (Sardo \& Alves, 2018). This finding proves that the adoption of ERP into the company business process provides a positive impact on corporate performance. However, the use of information technology did not guarantee the presence of a benefit for the company except that the information technology meets the criteria such as reliable, easy-to-access, integrated, flexible, accurate, complete and well-formatted information (Daradkeh \& Al-Dwairi, 2017). This finding indicated that the user of ERP, one of the kinds of IT used by the company, should pay attention to these notices before deciding to adopt the ERP system.

The purchasing strategy is one factor that improves the competitive advantage of the company. Principally, the primary goal of the purchasing strategy is to establish long-term cooperation with the supplier within the scope associated with new product developments, improving the quality of services and goods, and sharing of ideas that can improve product innovation. The purchasing strategy is longterm planning to meet the company's material needs related to the process of evaluating suppliers, selecting and determining suppliers, determining material prices by negotiating with suppliers, seeking potential suppliers for the company (Chiang et al., 2012). Furtherly, in enhancing the cooperation between both parties, the organization needs to develop its suppliers in respect of flexibility, delivery, and cost which are required to optimize the overall operations of the enterprise. In the same sense, top management should encourage an excellent relationship between the related department within the company which correlates with the material purchasing process in supporting the production. This functional relationship allows all related department to receive precise information regarding the product specifications, quantity, and delivery schedule.

Top management commitment is also another factor which can enhance the competitive advantage. Top management should proactively establish supply chain partnership for continuous collaboration with the supplier in developing the product and building a competitive advantage (Sauer \& Seuring, 2017). Leadership has an essential role in determining the success of a company in facing the competition. The leadership is defined as the ability of a person to influence and direct the group or team he leads to be able to achieve goals both on long-term and short-term. The leader should have the ability in managing corporate resources and determining the appropriate strategy to adapt to external changes which are reflected by the business strategy. A leader should also be able to facilitate the innovation of the products or processes (Tarigan, 2018). The leadership is also reflected in the form of 
Top management commitment, which determines the success or failure of the ERP implementation in supporting innovation activity within the company (Lee et al., 2016).

Those previous studies, so far, have primarily concentrated on three main concerns, i.e., first, the user of ERP (Park et al., 2007; Wu \& Wang, 2007; Larsen, 2009; Zhu et al., 2010; Ajer \& Hustad, 2015; Matende \& Ogao, 2013); second, the implementation of ERP (Nicolaou \& Bhattacharya, 2006; Hallikainen, et al., 2009; Hsu et al., 2015;); and third, ERP information quality (Zhou et al., 2014; Marinagi et al., 2015). Moreover, those researches have focused only on the direct influence of top management commitment, ERP integration, and purchasing strategy on the competitive advantage, and to the best of the authors knowledge, very few studies that take into account the relationship of the four constructs simultaneously. This study fills the gap by examining the influence of Top management commitment on the competitive advantage through the mediating role of ERP integration and purchasing strategy. This topic, consequently, raises six research questions to be examined which are 1) whether Top management commitment affects the ERP integration, 2) whether Top management commitment affects purchasing strategy, 3) whether ERP integration has impact on the purchasing strategy, 4) whether Top management commitment affects competitive advantage, 5) whether ERP integration influence competitive advantage, and 6) whether purchasing strategy influence competitive advantage. In addition to these direct influence, this paper also examines whether ERP integration and purchasing strategy mediates the influence of top management commitment on the competitive advantage. The result of this study will provide a new insight for the practitioner and enrichment on the current research on supply chain management.

\section{THEORETICAL REVIEW}

\section{Competitive Advantage and ERP Integration}

The company should build competitive advantages to outperform its competitors (Li et al., 2006). In the perspective of the supply chain management, competitive advantage is reflected in term of cost, customer, delivery, flexibility, quality, and responsiveness (Sundram, et al., 2018; Li et al., 2006). Production cost determines the price of the product. When the cost of production is lower than that of the competitor, the company product will be able to compete in the marketplace. In the same sense, when the product is delivered as promised, the customer will be satisfied and become loyal. Indicators used in competitive advantage are cost, customer satisfaction, inventory reduction, flexibility, responsiveness, and resource utility.

The benefit for the company from using ERP in integrating all departments in the company are the efficiency in administration function and the availability of adequate data in the pursuit of controlling the company's inventory (Shee et al., 2018). ERP implementation in the company reduce the cost of producing goods and providing services, without sacrificing the level products or services quality and still meet the specified specifications and the service level. In other words, the implementation of ERP enables the company to enhance its competitiveness regarding costs, strategic decision making, flexibility, responsiveness, flexibility, and process improvement (Nikookar et al., 2010).

The integration of the system in manufacturing companies allow the conveying of information in real-time between departments and individual as well. Information retrieved in real-time provides higher flexibility and responsiveness in facing any external changes. Chen \& Lin (2009) suggest that ERP implementation provides reliable data availability, which reduces cycle time, speeds up transactions, allows better control of the budget, and plans corporate financial arrangements. The integration of the system allows each functional to see other processes of the other functions such that all functions work in the same rhythm (Jacobs \& Weston, 2007). ERP can integrate internal processes such as financial, accounting, production, purchasing, and human resources (Nikookar et al., 2010). By integrating Inter-functional, it makes it easy to retrieve data from all departments required in preparing reports for the management in the pursuit of right decision making. Indicators specified are data accuracy between departments, completeness of data between departments, transparency of data between departments, reliable data, and data integration in real-time (Huo et al., 2014).

The advantages for the company from using ERP to integrate all departments in the company are the benefit of efficient administration and provision of adequate data availability in controlling the company's inventory. ERP implementation in the company emphasizes cost emphasis. Companies in 
producing goods and providing services with the lowest cost, but the quality of products still meet the specified specifications. The company implements ERP in enhancing its competitiveness has the motive to reduce costs, strategic decision making, better customer response, improvement process in the company (Nikookar et al., 2010).

Research conducted by Hallikainen et al. (2009) states that the business scope and technology scope must be matched and determined by the top management of the company to support the competitiveness of the company. Business scopes in companies represented in strategic business decisions on business and defined tactical business decisions up to the operational business decisions stage (Chugh et al., 2017). While technology scope consists of strategic technology decisions, tactical technology decisions, and operational technology decisions, module sequencing decisions will determine business scopes and technology scopes on each ERP module (Iris \& Cebeci, 2014). Integration between the ERP module and business functions will make the company's operational system effective and efficient.

The companies usually have a system and procedure starting from the orders receipt by the marketing department, processing orders into a production plan, calculating material requirements, procurement of material, production realization, and costing process by the accounting and finance department. Those stages of the process are connected through ERP systems, which provides data in real-time, fast, easy to retrieve, and efficient (Jagoda \& Samaranayake, 2017). ERP integrates all departments which are related to the production and automatically calculate the needs of finished products and by using bill of material (BOM) data to support the production schedule (Monostori et al., 2010).

\section{ERP integration and Purchasing Strategy.}

Purchasing is one of the organizational structure and also as a function that was generally in material procurement, sub-material, components, and stationery (Namukasa, 2017). Responsibility on the purchasing is to get goods that fit the needs of the company associated with the quantity and quality of goods used by the company to maintain the smooth operation of the company's system. Purchasing has one goal to get the efficiency and effectiveness of the company's operations because it is directly connected with other departments, especially on the operational (Sweeney et al., 2018). In companies that have implemented ERP, they are integrated with all departments within the company (Huo et al., 2014). The role of purchasing has the potential to create the competitiveness of the company, as it can maintain and improve time to market, product quality, and quantity, as well as increased responsiveness. Manufacturers generally use strategy selected in the procurement of materials (Sundram et al., 2018). The purchasing strategy is long-term planning to meet the company's material needs related to the process of evaluating suppliers, selecting and determining suppliers, determining material prices by negotiating with suppliers, seeking potential suppliers for the company (Chiang et al., 2012). The purchasing strategy is run by a purchasing manager who can perform data analysis primarily on costs, an understanding of the supply market, the ability to negotiate and develop contracts, communication skills and effective presentation of purchasing strategies.

Purchasing strategy established by the company to be able and able to establish long-term relationship cooperation with the supplier (Kim et al., 2015). Relationships and communications built by purchasing parties with suppliers associated with new product developments, improving the quality of services and goods, share ideas that can improve product innovation. In improving the efficiency of the procurement of raw materials, the purchasing party must be able to develop its suppliers so that the level of flexibility of the company's production increases will increase the company's competitiveness. Working well with suppliers will help the company to manage and optimize the company's operations that will improve the company's profit. A good relationship is also done by the department of purchasing with other departments related to material demand in the purchasing department (Namukasa, 2017). Requests from other departments to the purchasing department should provide precise information to facilitate a shared understanding of product specifications requested by other departments. Clarity of information obtained will facilitate purchasing to procure raw materials and excellent communication with the supplier. Companies that have implemented ERP generally use data integration to avoid miscommunication with other departments (Motiei et al., 2015). Implementation of ERP on the purchasing then all materials have an identification (ID) of individual material and its specification. 
Manufacture companies in East Java mostly use the strategy of multiple sourcing. This strategy relies on the process of comparing offers from many suppliers to select one the best. The supplier is assigned to take all responsibility in developing its business and product innovation in order to fulfill the company request. This condition resulted in intense competition from suppliers and competing with each other aggressively. Despite many negotiation approaches used in this strategy, however, long-term relationships are not the primary objective. Indicators used to measure purchasing strategy are: determining potential suppliers, developing suppliers for the company benefit, contracting with suppliers, having long-term plannin, and evaluating suppliers on an ongoing basis.

\section{Purchasing strategy and competitive Advantage}

The purchasing strategy adopted by the company is aimed at establishing long-term relationship cooperation with the supplier. Relationships and communications built by purchasing parties with suppliers are essential to involve the supplier in the process of new product developments, improvement of the quality of services and goods, and share ideas that can improve product innovation as well. The relationship between purchaser and supplier is also required in enhancing the efficiency of the procurement of raw materials. The buyer, therefore, needs to develop and manage its suppliers in term of flexibility and responsiveness, which, in the end, will increase the company's competitiveness. Working well with suppliers will help the company to manage and optimize the company's operations that will improve the company's profit. Besides the relationship with the supplier, purchasing department also needs to have a good relationship with other departments, particularly those which are related to the material procurement. With an established relationship, other departments will provide precise information, particularly in respect of material specifications required by using the standardized identification of each material. Purchasing department, consequently, will be able to procure raw materials from the supplier.

Utilization of this information technology allows the purchasing department to establish an effective procurement strategy (Sundram et al., 2018). Purchasing departments can communicate and collaborate well with suppliers. Strategic procurement for the company can increase the sourcing capability to reach an agreement between suppliers with the company (Kim et al., 2015). The use of integrated information technology can improve the business process quickly and accurately to maintain the company's advantage (Nikookar et al., 2010). The purchasing strategy is a process of planning, implementation process, supervision process, and evaluation process to the supplier. This process is essential to maintain supplier performance consistency. Purchasing strategy affects company performance and business performance and ultimately gives the company competitiveness (Semuel et al., 2018). The ability of the purchasing department to procure materials at a Kenyan manufacturing company provides an improvement to the company's operational performance (Susan \& Wagoki, 2014). The purchasing strategy is established to provide competitiveness for the company.

Manufacture companies mostly use the purchasing strategy that involves many suppliers. This strategy compares the offers from that supplier to get the best offer. This condition resulted in intense competition from the suppliers and the negotiation with the supplier focused on the gain for the one and loss for the other. Despite many negotiation approaches used in this strategy, however, long-term relationships are not the primary objective. Purchasing strategy assesses the extent to which the company select the potential best suppliers, develops the suppliers, administer a contract with suppliers, having long-term planning, and evaluating suppliers on an ongoing basis.

\section{Top Management Commitment and ERP integration.}

Leadership is an essential factor in determining the success or failure of a company. Leadership is the ability of a person to influence and direct the group or team he leads to be able to achieve goals or goals that have been set, both on long-term goals and short-term goals. The ability of a leader in managing corporate or organizational resources and the ability of a leader to determine the right strategy to adapt to external changes to fit the business cycle will affect the company's position and sustainability. The company needs a reliable and capable leader to direct all of the company activity to face competition. A leader must create an innovation environment to enable the activity of product and processes innovation. Innovation by some companies by implementing ERP technology and keeping it in line 
with external changes, this success is determined by the commitment of top management (Lee et al., 2016).

Top management is responsible for encouraging the organization to continuously innovate as a response to the continually changing business environment and to develop and upgrade organizational capability (Ismail \& Mamat, 2012). Top management is also responsible for defining the business strategy through a short-term and long-term goal. Top management of the company needed its commitment to be able to organize, manage, and control throughout the company's activities to be a winner in the global competition. Enterprise management can create an environment and inspiration for all workers to be able to create efficiency, effectiveness, grow, and develop the potential of employees to win the competition. Company management can ensure that the company is at its core competency (Suprapto et al., 2017). Competence owned by the company to create a product or service suitable for the customer's desire to create competition. Management can integrate all resources to obtain the best practice for the company. The integration that companies use in information technology systems is ERP (Motiei et al., 2015). The development of an ERP system for a company is a task of top management visible from its commitment (Ke \& Wei, 2008). Top management commitment is a management capability to organize members within the organization of the company and control it to achieve the goals that have been set. The indicators used to measure the commitment of top management are: the management establishes the company's goals. The management plans the employee development, the management provides employee training, the management works hard to succeed the goals, the management provides resources as needed, and the management periodically evaluates the system.

\section{Top management commitment and purchasing strategy.}

Top management facilitates the purchasing department in enhancing an appropriate employee competency in the field of the procurement process. The top management has the role of directing the purchasing department to adopt an appropriate purchasing strategy such as green purchasing (Yen \& Yen, 212). In achieving the goals, top management establishes a plan in developing employees ability in determining and evaluating suppliers on an ongoing basis. Truong et al., (2017) suggest that top management commitment provides a positive impact on supplier relationship and customer focus ad hence, top management can conduct control and improvement for the pursuit of increased firm performance. However, another research by Ramakrishnan et al. (2015) is different from previous research. This study stated that the top management commitment did not influence the purchasing strategy in adopting the green purchasing strategy at small manufacturing enterprises in Malaysia. From these two contrary results, this study adopts the result from the research by Yen \& Yen (2012), which state that top management commitment has an impact in defining the purchasing strategy.

\section{Top management commitment and competitive advantage.}

Top management commitment can directly increase the competitive advantage. One of the top management roles is to make a set of decision and policy in creating a competitive advantage for the company. Top management is committed and working hard to achieve the company goals through the enhancement of employee competence and the provision of the resources required in achieving customer satisfaction. Research by Ferri \& Pedrini (2018) states that top management can improve the corporate performance which furtherly, provides an impact on the competitive advantage of the company. Research conducted by Hallikainen et al., (2009) states that that business scope and technology scope must match and be determined by the company's top management to create the company's competitive advantage. Business scopes are represented in the strategic business decisions, tactical business decisions, and operational decisions of the business stage. While technology scope consists of strategic technology decisions, tactical technology decisions, and operational technology decisions, business scope, and technology scope will be executed respectively by as sequenced on the ERP module (Iris \& Cebeci, 2014). The integration between the ERP module and business functions will make the company's operational system effective and efficient, which subsequently results in a competitive advantage for companies.

The competitive advantage of a company constitutes a superiority owned by a company to compete in the market they serve. The competitive advantage can be in the form of products characteristics or 
company resources performing much better than the competitor in the same market (Elshaer \& Augustyn, 2016). The ability of a company to create a competitive advantage enables the company to provide a valuable benefit to the customer, and in the end, the company will enjoy the growth of customer demand for the product from the local, regional and international request. The indicators used in competitive advantage are cost reduction, customer satisfaction, inventory reduction, increased corporate flexibility, customer responsiveness, and increased utility of company resources.

\section{Hypotheses Development}

The previous discussion on theoretical review demonstrated that a company such as a manufacturer would be able to enhance their competitiveness through product innovation or process innovation in improving the company performance (Tarigan, 2018). Manufacturing companies create and enhance their competitive advantage for outperforming their competitors. The competitive advantage is highly necessary for today intensifying competition either in the local, regional, or international market. Hence, top management of the company has no choice other than to adopt information technology systems into their operational practices in integrating the internal and external function (Riley et al., 2016). Integration of internal and external function of a company function such as using enterprise resources planning (ERP) enables manufacturing companies to be more agile and flexible in response to the market demand (Khalaf \& Mokadem, 2019). All functions involved in a process within a company will obtain the data from the same sources easily, quickly and thoroughly. Another benefit of using ERP technology in integrating the function is that it allows the company to realize the purchasing strategy of manufacturing companies (Huo et al., 2014). The research framework for this study can be described as indicated in Figure 1, and six hypotheses are proposed as follows:

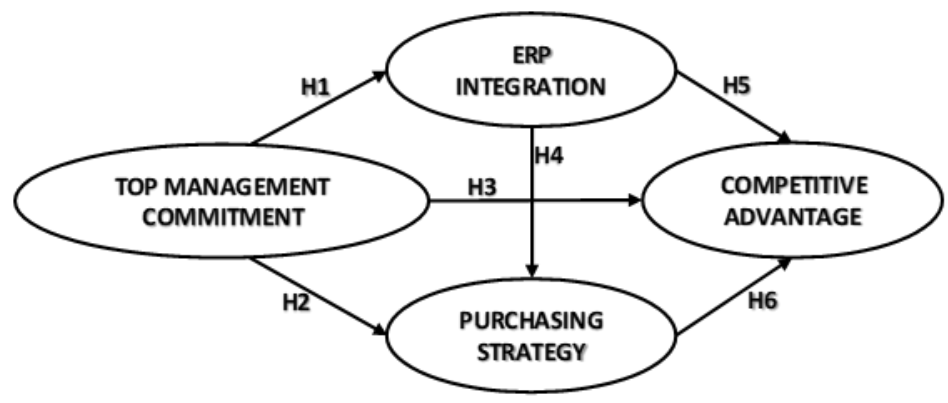

Figure 1. Research Model

H1: Top management commitment influences ERP integration.

H2: Top management commitment influences the purchasing strategy.

H3: Top management commitment influences the competitive advantage.

H4: ERP integration affects the purchasing strategy

H5: ERP integration influences the competitive advantage.

H6: Purchasing strategy affect the competitive advantage.

\section{RESEARCH METHODOLOGY}

Data for this study was collected using questionnaires distributed to manufacturing companies in East Java, Indonesia. The questionnaire was designed using a five-point Likert scale ranging from 1: strongly disagree up to 5: strongly agree. Sampling frame used purposive sampling technique which meets three criteria which are: first, the companies have implemented ERP (in the form of SAP products, Oracle, Microsoft dynamics, people soft, MFG Pro, and the development of their ERP systems); second, the companies have implemented data integration in the purchasing department; third respondents have middle-level managers in the company. The reason for the criteria is to make sure that the information obtained from the respondents coincide with the operational conditions of the company. Based on the data gathered from the bureau statistic, there are 124 manufacturing companies domiciled in the region 
of east java, Indonesia. After through detailed review, we found there are 60 companies which fulfilled the criteria. These companies consist of food and beverage, garment, cigarette, and chemical manufacturing. Those enterprises not included in the survey are not engaged in the manufacturing process but engaged in the supporting sector such as supplier, distributor, and retailer. The questionnaires were distributed to the sixty companies through postal for the company located far from the city, and hand carries to the companies located close to the city. It takes six weeks to distribute and collect the data. From sixty questionnaires, forty-nine questionnaires are correctly administered for the next analysis. All of the respondents are composed of different position in the organization structure. There are three owners, two general managers/plant managers, twenty managers, fifteen assistant manager, one supervisor, and eight officers. This composition shows that all the position in the organization structure, especially the purchasing department, have been represented. The working experience of the respondents also indicated that they have adequate working experience, knowledge, and competencies. Based on the working experiences, the respondents have various range of working experiences, i.e., three respondents with less than one year; four respondents between one to three years; five respondents between three to five years; twelve respondents with working experience between five to ten years; and twenty five respondents with working experience more than ten years.

The enterprises which are involved in this study used various type of ERP software. There are twenty-two companies used SAP software, eight companies used Oracle software, three companies used Microsoft dynamics software, one company used MFG Pro software, and 15 companies develop their ERP system. Those companies involved in the survey are of the different size in respect of employees. There are three companies which have less than 100 workers, twelve companies have between 100 up to 200 employees, five companies have 200 up to 300 employees, two companies have 300 up to 400 workforces, eight companies have 400 up to 500 workforce, and nineteen companies have more than 500 workforces. Partial Least Square (PLS) technique was used to analyze the data. The use of the PLS technique is a well-established approach, particularly in the case of a small number of the respondent and limited theory such as on this study.

\section{RESEARCH RESULT}

The first set of analysis examined the measurement model to assess validity and reliability. Meanwhile, the second set of analysis tested the hypotheses proposed based on the literature review. Table 1 demonstrated the result of the measurement model assessment. As shown, all indicator has the factor loading ranges from 0.550 up to 0.888 , which are higher than 0.5 as the minimum recommended value (Motiei et al., 2015). This result proved that all indicators are highly correlated with its variable and appropriate to become the indicator of the variable. Beside the convergent validity, discriminant validity is another measurement which compares between the factor loading and the cross-loading with other variables. As shown in Table 1, those factor loading of indicators is higher than its cross-loading with another variable. This result means that those indicators are more correlated with their variable than with other variables. Hence, the measurement model is considered valid.

The next assessment of the measurement model is reliability. Reliability assesses the extent to which the block indicators of each variable provides consistent result during different moment and situation. Cronbach alpha, composite reliability, and average variance extracted (AVE) measure the reliability of the measurement model. Table 2 indicated the reliability regarding the three measurements. The Cronbach alpha and composite reliability have the value which ranges from 0.690 up to 0.901 . Those values are higher than 0.600 as the minimum accepted value.

Meanwhile, the AVE ranges from 0.484 up to 0.606 . The minimum accepted value for the AVE is 0.500 . Since the lowest value of AVE closely approach 0.500 , and the other reliability measurements are accepted, we considered the AVE value of 0.484 is acceptable. Based on this result, we conclude that the measurement model is valid and reliable. Table 2 also indicated that the value of R-square for the three dependent variables, i.e., ERP Integration, Purchasing strategy, and Competitive Advantage. Those value of the R-square ranges from low (0.234) and moderate (0.425 and 0.651$)$. This value means that the affecting variable moderately explains the variance of the dependent variable. 
Table 1

Factor Loading and Cross Loading of Indicators

\begin{tabular}{lccccc} 
& & \multicolumn{4}{c}{ Cross Loading } \\
\cline { 3 - 5 } Variable/Indicator & $\begin{array}{c}\text { Factor } \\
\text { Loading }\end{array}$ & $\begin{array}{c}\text { Top } \\
\text { management } \\
\text { commitment }\end{array}$ & $\begin{array}{c}\text { ERP } \\
\text { Integration }\end{array}$ & $\begin{array}{c}\text { Purchasing } \\
\text { Strategy }\end{array}$ & $\begin{array}{c}\text { Competitive } \\
\text { Advantage }\end{array}$ \\
& & &
\end{tabular}

Top management commitment

Management set the

company goal clearly

0.550

0.283

0.357

0.269

(X1.1)

The management plan

the development of the

0.782

employees (X1.2)

Management provides

training (X1.3)

0.759

Management works hard

to succeed in the goal

(X1.4)

Management provides

resources according to

the needs (X1.5)

Management periodically

evaluates the enterprise

system (X1.6))

0.675

0.888

0.319

0.391

ERP Integration

ERP provides an accurate

data between

$0.661 \quad 0.288$

0.363

0.511

0.649

departments (X2.1)

Completeness of data

between departments

(X2.2)

Transparency of data

between departments

(X2.3)

Reliability of data (X2.4)

0.462

0.521

0.349

0.441

Real-time data integration

(X2.5)

$0.806 \quad 0.501$

0.261

0.414

0.504

Purchasing Strategy

Determining potential

suppliers (X3.1),

Developing suppliers for

the company (X3.2)

Making contracts with

$0.818 \quad 0.405$

0.385

0.315

0.362

suppliers (X3.3)

$0.639 \quad 0.264$

0.425

0.41

Having a long-term plan

(X3.4)

0.639

0.577

0.71

Evaluating suppliers continuously (X3.5)

$\begin{array}{lll}0.81 & 0.494 & 0.646\end{array}$

0.268

0.368

Competitive Advantage

Cost reduction (Y1.1)

0.606

0.208

0.093

0.792

0.378

0.408

0.358

0.323

Customer satisfaction

(Y1.2)

Inventory reduction (Y1.3)

Increased flexibility of the

company (Y1.4)

0.606

0.208

0.187

0.355

Customer responsiveness

(Y1.5)

0.622

0.257

0.39

0.234

0.656

0.394

0.39

0.361

Increase in the company's

resource utility (Y1.6)

0.693

0.376

0.338

0.416

\begin{tabular}{llll}
0.759 & 0.547 & 0.495 & 0.509 \\
0.868 & 0.552 & 0.707 & 0.792 \\
0.804 & 0.472 & 0.45 & 0.532 \\
0.759 & 0.568 & 0.49 & 0.498 \\
\hline 0.61 & 0.257 & 0.286 & 0.215 \\
\hline 0.844 & 0.494 & 0.469 & 0.618
\end{tabular}


Table 2

Reliability and R-square of Construct

\begin{tabular}{lcccc}
\hline \multicolumn{1}{c}{ Construct } & R-square & $\begin{array}{c}\text { Cronbach } \\
\text { Alpa }\end{array}$ & $\begin{array}{c}\text { Composite } \\
\text { Reliability }\end{array}$ & AVE \\
\hline Top management commitment & - & 0.829 & 0.876 & 0.545 \\
\hline ERP integration & 0.234 & 0.791 & 0.853 & 0.540 \\
\hline Purchasing Strategy & 0.425 & 0.690 & 0.810 & 0.484 \\
\hline Competitive Advantage & 0.651 & 0.870 & 0.901 & 0.606 \\
\hline
\end{tabular}

The value of those $\mathrm{R}$-squares allows the assessment of the predictive relevance, denoted by Qsquare $=1-\left(1-R_{1}^{2}\right)\left(1-R_{2}^{2}\right)\left(1-R_{3}^{2}\right)$, which means how robust the model of this study can predict the dependent construct which is a competitive advantage. The Q-square for the model is 0.91 . As the value approach one, it means this model has an excellent predictive relevance, which means the model applies to enhance the competitive advantage. Figure 1 demonstrated the research model and the result of the data analysis.

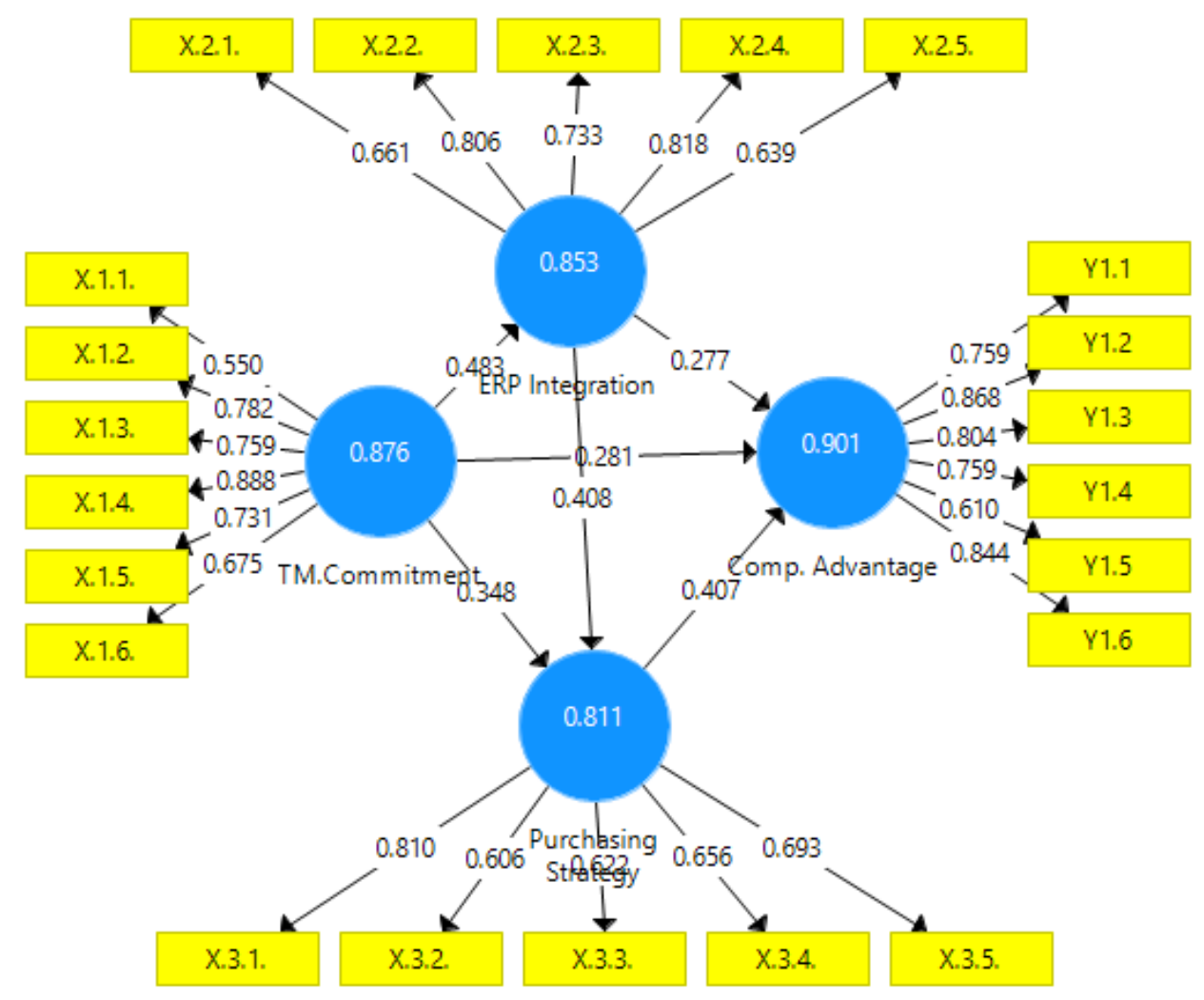

Figure 1. Research Model and Analysis Result

The subsequent analysis is to assess the path coefficient of each relationship and its significance to examine the six hypotheses. The result of the hypotheses testing can be seen from the Partial Least Square output, as indicated in Table 3. 
Table 3

Path Coefficient and T-value of Relationship

\begin{tabular}{|c|c|c|c|c|}
\hline Hypothesis & $\begin{array}{c}\text { Orig. } \\
\text { sample } \\
\text { estimate }\end{array}$ & $\begin{array}{c}\text { Mean of } \\
\text { subsamples }\end{array}$ & $\begin{array}{l}\text { Standard } \\
\text { deviation }\end{array}$ & $\begin{array}{l}\text { T- } \\
\text { Statistic }\end{array}$ \\
\hline ManagementCommitment->ERP Integration (H1) & 0.483 & 0.522 & 0.106 & 4.567 \\
\hline $\begin{array}{l}\text { Top management commitment -> Purchasing strategy } \\
(\mathrm{H} 2)\end{array}$ & 0.348 & 0.347 & 0.134 & 2.605 \\
\hline $\begin{array}{l}\text { Top management commitment-> Competitive } \\
\text { advantage }(\mathrm{H} 3)\end{array}$ & 0.281 & 0.289 & 0.133 & 2.113 \\
\hline ERP Integration -> Purchasing Strategy (H4) & 0.408 & 0.431 & 0.124 & 3.296 \\
\hline ERP Integration -> Competitive advantage (H5) & 0.277 & 0.267 & 0.119 & 2.328 \\
\hline Purchasing strategy-> Competitive advantage (H6) & 0.407 & 0.409 & 0.126 & 3.233 \\
\hline
\end{tabular}

Table 3 indicated that those six hypotheses are supported by the empirical data collected from the manufacturing industry in the region of East Java, Indonesia. The first hypothesis which states that Top management commitment positively affects ERP integration is supported with the coefficient of 0.483 and the t-value of 4.567 (higher than 1.96 for $5 \%$ significant level). The finding proves that top management commitment is to set goals and develop the company employees capability for the implementation and maintenance of the ERP integration. The ERP integration supported by the capable employee will allow the provision of the appropriate and reliable data required in decisions making. This result supports the previous studies, which revealed that Top management commitment has an impact on the ERP integration implementation (Matende \& Ogao, 2013 and Soja, 2006).

The second hypothesis, which stated that Top management commitment influence the purchasing strategy is also supported by the empirical data from the manufacturing companies in East Java. This result is shown by the path coefficient of 0.348 and the t-value of 2.605. Top management establishes the company goals, train, and develop the employee through training to build up the purchaser competency in identifying and evaluating the potential suppliers. This finding supports the research by Yen \& Yen (2012), which states that Top management commitment affects the purchasing strategy of adopting green purchasing standard. This finding is also in line with the work by Truong et al., (2017) suggesting that top management commitment provides a positive impact in the pursuit of firm performance in enhancing the supplier management.

However, this research is different from the study by Ramakrishnan et al. (2015) which stated that the Top management commitment gives no effect on the purchasing strategy in green purchasing for the small manufacturing enterprises in Malaysia. As expected, hypotheses three, which state that Top management commitment affects competitive advantage is also supported. This fact is shown by the path coefficient of 0.281 and the $t$-value of 2.113 (higher than 1,96 for the significant level of 5\%). This finding proves that company management through the establishment of the goals and policies, and the training of the employee contributes to improving customer satisfaction. This finding supports the research by Ferri \& Pedrini (2018) which states that Top management commitment positively contributes to the company performance that ultimately impacts on the competitive advantage.

The fourth hypothesis which states that ERP integration gives an impact on the purchasing strategy as shown by the coefficient of 0.408 and the $t$-value of 3.296 The result demonstrated that the purchasing department highly requires the company to integrates the data between departments and make data available on ERP systems. Once the data are available in the ERP system, the purchasing section can evaluate and determine potential suppliers on an ongoing basis. This study supports the research of Suliantoro et al., (2015) which states that system integration can help the process of e-procurement.

The fifth hypothesis which states that the ERP integration system affects the competitive advantage with the path coefficient of 0.277 and the $t$-value of 2.328 . This result provides proof that the availability of data shared between departments allow all departments to access and analyze the same data. The availability of the same data between all department allows the organization to serve the customer in a much better way that customers are satisfied. This study supports the research by Mohamad et al., (2017) which states that the implementation of ITC (information technology capability) as an integrated system provides the impact of corporate innovation in building competitive advantage. Thus 
enhancement of scope technology can provide the increased scope of business development (Hallikainen et al., 2009). This research also supports the research of Ya'kob \& Jusoh (2016) stating that information sharing in the form of data integration in ERP can provide improved performance to enhance the competitiveness of companies.

The last hypotheses (sixth hypotheses) which state that purchasing strategy influences the competitive advantage is supported by the empirical data as well. The continuous evaluation of suppliers will push the supplier to provide the best service to the corporate and consequently, the company will be able to provide the best product or service to the company. In other words, purchasing strategy support the company to serve the customer in the best manner and finally improve the competitive advantage of the company. This study supports the research by Ferri \& Pedrini (2018) and Kim et al., (2015) stating that the purchasing process as a form of strategy can provide economical performance and competitiveness.

One of the objectives of this research is to explore the role of the ERP integration and purchasing strategy in the relationship between top management commitment and the competitive advantage. As indicated in the previous discussion, those six hypotheses of the direct impact are supported by the empirical data. This finding, consequently, means that the indirect relationships between constructs are present. Hence, top management commitment also indirectly and positively improve the competitive advantage through the mediating role of the ERP integration and the purchasing strategy in dealing with best suppliers. This finding of indirect effect implies that the management of the manufacturing companies in the region of East Java, Indonesia needs to establish an ERP integration in providing the data source in a timely and accurate manner. This result also revealed that the establishment of an appropriate purchasing strategy is necessary to reinforce the influence of top management commitment in enhancing competitive advantage.

\section{CONCLUSIONS}

The objective of the present work paper is to examine the role of top management commitment on competitive advantage through ERP integration and purchasing strategy. The result of the study indicated that those six hypotheses are supported. Top management commitment influences the integration of the ERP system. Furtherly, top management commitment supports the purchasing department in applying an excellent purchasing strategy through continuous supplier evaluation and development. Top management commitment also contributes to the creation of the competitive advantage of the enterprise. Integration of existing data on the company through the ERP application also allows the purchasing department to accurately determine an appropriate purchasing strategy providing benefit to the company. The ERP integration by the enterprise enables all department to be integrated and provide the benefit in term of accurate data, quick response, and reduced cost which in the end increasing the competitive advantage of the company. Another finding from this study is the fact that Strategy purchasing influences the competitive advantage through the achievement of lower cost, best support from a supplier in term of quality and flexibility. The most exciting finding of this study is the fact that ERP integration and purchasing strategy mediates the influence of top management commitment on the competitive advantage. This establishment of the ERP integration and purchasing strategy by the top management provide an additional indirect impact of the top management commitment in affecting the competitive advantage. Hence, top management commitment, in total, enhance the competitive advantage in a higher impact than that of only direct impact. This result provides insight for the manufacturing practitioner and paves the way for the manager in enhancing the competitive advantage through the establishment of the ERP integration and the determination of the proper purchasing strategy. Beside managerial contribution, this result of the study also contributes to the enrichment of the current research in the field of supply chain management.

\section{REFERENCES}

Ajer, A. K. \& Hustad, E. (2015). Enterprise system implementation in a franchise context: an action case study. Procedia Computer Science, 64, 948 - 956. 
Chen, S.-G., \& Lin, Y.-K., (2009). On performance evaluation of ERP systems with fuzzy mathematics. Expert Systems with the Application, 36 (2P2), 6362-6367.

Chiang, C.-Y., Kocabasoglu-Hillmer, C., \& Suresh, N. (2012). An empirical investigation of the impact of strategic sourcing and flexibility on a firm's supply chain agility, International Journal of Operation and Production Management, 32(1), 49-78.

Chugh, R., Sharma, S.C., \& Cabrera, A. (2017). Lessons learned from enterprise resources planning (ERP) implementations in the Australian company, International Journal of Enterprise Information Systems, 13(3), 23-35.

Daradkeh, M., \& Al-Dwairi, R. M. (2017). Self-service business intelligence adoption in business enterprises: The effects of information quality, system quality, and analysis quality. International Journal of Enterprise Information Systems, 13(3), 65-85.

Elshaer, I.A., and Augustyn, M.M. (2016). Direct effects of quality management on competitive advantage, International Journal of Quality \& Reliability Management, 33 (9), 1286-1310.

Ferri, L.M. \& Pedrini, M. (2018). Socially and environmentally responsible purchasing: comparing the impacts on buying a firm's financial performance, competitiveness, and risk, Journal of Cleaner Production, 174, 880-888.

Hallikainen, P., Kivijärvi, H., \& Tuominen, M. (2009). Supporting the module sequencing decision in the ERP implementation process an application of the ANP method, International Journal Production Economics, 119, 259-270.

Hsu, P.F., Yen, H. R. \& Chung, J.C. (2015). Assessing ERP post-implementation success at the individual level: Revisiting the Role of service quality, Information \& Management, 52, 925-942.

Huo, B., Qi, Y., Wang, Z., \& Zhao, X. (2014). The impact of supply chain integration on firm performance: the moderating role of competitive strategy, Supply Chain Management: An International Journal, 19(4), 369-384.

Iris, C., \& Cebeci, U. (2014). Analyzing the relationship between ERP utilization and lean manufacturing maturity of Turkish SMEs, Journal of Enterprise Information Management, 27(3), 261277.

Ismail, A., \& Mamat, M. (2012). The relationship between information technology, process innovation, and organizational performance. International Journal of Business and Social Science, 3(2), 268-274.

Jacobs, F.R., \& F.C. T. Weston. (2007). Enterprise resources planning (ERP)-a brief history, Journal of Operation Management, 25(2), 357-363.

Jagoda, K., \& Samaranayake, P. (2017). An integrated framework for ERP system implementation, International Journal of Accounting \& Information Management, 25(1), 91-109.

Ke, W. \& Wei, K.K. (2008). Organizational Culture and Leadership in ERP implementation, Decision Support System, 45(2), 208-218.

Khalaf, M.A. \& Mokadem, M.Y.E. (2019). The relationship between internal integration and manufacturing flexibility in the Egyptian industry, International Journal of Quality and Service Sciences, 11(1), 16-33. 
Kim, M., Suresh, N.C., \& Kocabasoglu-Hillmer, C. (2015). A contextual analysis of the impact of strategic sourcing and E-procurement on performance, Journal of Business \& Industrial Marketing, 30 (1), 1-16

Larsen, T.J. (2009). A multilevel explanation of end-user computing satisfaction with an enterprise resources planning system within an international manufacturing organization, Computers in Industry, 60, 657-668.

Lee, J.C., Shiue, Y.-C., \& Chen, C-Y. (2016). Examining the impacts of organizational culture and top management support of knowledge sharing on the success of software process improvement, Computers in Human Behavior, 54, 462-474.

Li, S., Ragu-Nathan, B., Ragu-Nathan, T.S., \& Rao, S.S. (2006). The impact of supply chain management practices on competitive advantage and organizational performance, Omega, 34, 107-124.

Marinagi, C. Trivellas, P. \& Reklitis, P. (2015). Information quality and supply chain performance: the mediating role of information sharing, Procedia-Social, and Behavioral Sciences, 175, 473 - 479.

Matende, S. \& Ogao, P. (2013). Enterprise Resource Planning (ERP) system implementation: a case for user participation, Procedia Technology, 9, 518-526,

Mohamad, A.A., Ramayah, T. \& Lo, M.-C. (2017). Knowledge management in MSC Malaysia: the role of information technology capability, International Journal of Business and Society, 18(S4), 651-660.

Monostori, L., Erdős, G., Kádár, B., Kis, T., Kovács, A., Pfeiffer, A., \& Váncza, J., (2010). Digital enterprise solution for integrated production planning and control, Computers in Industry, 61, 112-126.

Motiei, M., Zakaria, N.H., Aloini, D. \& Sekeh, M.A. (2015). Developing instruments for enterprise resources planning (ERP) post-implementation failure mode, International Journal of Enterprise Information Systems, 11(3), 68-83.

Namukasa, J. (2017). Records management and procurement performance a case of NAADS program in the central region of Uganda, Records Management Journal, 27(3), 256-274.

Nicolaou, A.I. \& Bhattacharya, S. (2006). Organizational performance effects of ERP system usage: the impact of post-implementation changes, International Journal of Accounting Information Systems, 7, 18-35.

Nikookar, G., Safavi, S.Y., Hakim, A. \& Homayoun, A. (2010). The competitive advantage of enterprise resources planning vendors in Iran, Information Systems, 35, 271-277.

Park, J.H., Suh, H.J. \& Yang, H.D. (2007). The perceived absorptive capacity of individual users in the performance of Enterprise Resources Planning (ERP) usage: the case for Korean firms, Information and Management, 44, 300-312.

Ramakrishnan, P., Haron, H. \& Goh, Y.-N. (2015). Factors influencing green purchasing adoption for small and medium enterprises (SMEs) in Malaysia, International Journal of Business and Society, 16(1), 39-56.

Riley, J.M., Klein, R., Miller, J. \& Sridharan, V. (2016). How internal integration, information sharing, and training affect supply chain risk management capabilities, International Journal of Physical Distribution \& Logistics Management, 46(10),953-980.

Sardo, F., \& Alves, M.-C. (2018). ERP systems and accounting: A systematic literature review. International Journal of Enterprise Information Systems, 14(3), 1-18. 
Sauer, P.C., \& Seuring, S. (2017). Sustainable supply chain management for minerals, Journal of Cleaner Production, 151, 235-249.

Semuel, H., Siagian, H. \& Arnius, R. (2018). The effects of strategic purchasing on organization performance through negotiation strategy and buyer-supplier relationship, International Journal of Business and Society, 19(2), 323-334.

Shee, H., Miah, S.J., Fairfield, L., \& Pujawan, N. (2018). The impact of cloud-enabled process integration on supply chain performance and firm sustainability: the moderating role of top management, Supply Chain Management: An International Journal, 23(6), 500-517.

Silvestre, B.S., Monteiro, M.S., Viana, F.L.E., \& Sousa-Filho, J.M.D. (2018). Challenges for sustainable supply chain management: When stakeholder collaboration becomes conducive to corruption, Journal of Cleaner Production, 194, 766-776.

Soja, P. (2006). Success factor in ERP implementation: lesson from practice. Journal of Enterprise Information Management, 19(6), 646-661.

Su, Y. \& Yang, C. (2010). Why are enterprise resource planning systems indispensable to supply chain management?. European Journal of Operational Research, 203, 81-94.

Suliantoro, H., Ghozali, I. \& Wibowo, M.A. (2015). E-procurement adoption in government institution: predicting social values effect on intention and usage behavior of e-procurement. International Journal of Business and Society, 16(2), 167-184.

Sundram, V.P.K., Bahrin, A.S., Munir, Z.B.A., \& Zolait, A.H. (2018). The effect of supply chain information management and information system infrastructure: The mediating role of supply chain integration towards manufacturing performance in Malaysia, Journal of Enterprise Information Management, 31(5), 751-770.

Suprapto, W., Tarigan, Z.J.H. \& S. R. Basana. (2017). The influence of the ERP system to the company performance seen through the innovation process, information quality, and information sharing as the intervening variables, ICEMT' 17, July 9-11, 2017, Singapore.

Susan, K.N., \& Wagoki, J. (2014). Effect of strategic material sourcing on operational performance of manufacturing firm: a case of East African Breweries Ltd., Kenya, International Journal of Science and Research (IJSR), 3 (11), 124-130.

Sweeney, E., Grant, D.B., \& Mangan, D.J. (2018). Strategic adoption of logistics and supply chain management, International Journal of Operations \& Production Management, 38(3), 852-873.

Tarigan, Z.J.H. (2018). The impact of organizational commitment to the process and product innovation in improving operational performance, International Journal of Business and Society, 19(2), 335-346.

Truong, H.Q., Sameiro, M., Fernandes, A.C., Sampaio, P., Duong, B.A.T., Duong, H.H., \& Vilhenac, E. (2017). Supply chain management practices and firms' operational performance, International Journal of Quality \& Reliability Management, 34(2), 176-193.

Wu, J.H. \& Wang, Y.M. (2007). Measuring ERP success: the key-users' viewpoint of the ERP to produce a viable IS in the organization, The computer in Human Behavior, 23, 1582 - 1596.

Ya'kob, S.A. \& Jusoh, W.J.W. (2016). The effect of supply chain linkage on micro and small enterprises' performance, International Journal of Business and Society, 17(1), 99-112. 
Yen, Y-X., \& Yen, S.-Y. (2012). Top management's role in adopting green purchasing standards in high-tech industrial firms, Journal of Business Research, 65(7), 951-959.

Zhou, H., Shou, Y., Zhai, X., Li, L., Wood, C. \& Wu, X. (2014). Supply chain practice and information quality: a supply chain strategy study, International Journal of Production Economics, 147, 624-633.

Zhu, Y., Li, Y., Wang, W. \& Chen, J. (2010). What leads to the post-implementation success of ERP? an empirical study of the Chinese retail industry, International Journal of Information Management, $30,265-276$. 


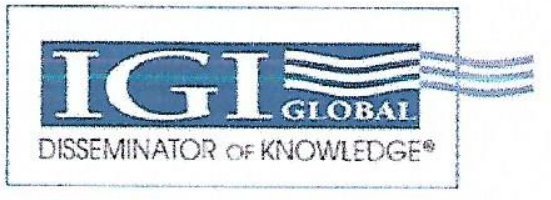

IGI Global

701 E. Chocolate Avenue

Hershey PA 17033-1240, USA

Tel: 717.533-8845; Fax: 717.533-8661

Publisher note: Changes to the text of this form, without the written permission of IGI Global are prohibited, and will void tinis agreement.

\section{IGI Global Publication Agreement}

Dear Contributor(s), We are pleased that you have selected an IGI Global publication for submitting your contribution. To minimize delays in the publication process, author(s) on your submission, or a designated lead author, must sign a copy of this form and submit

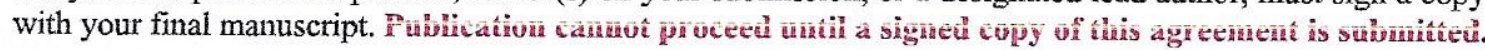

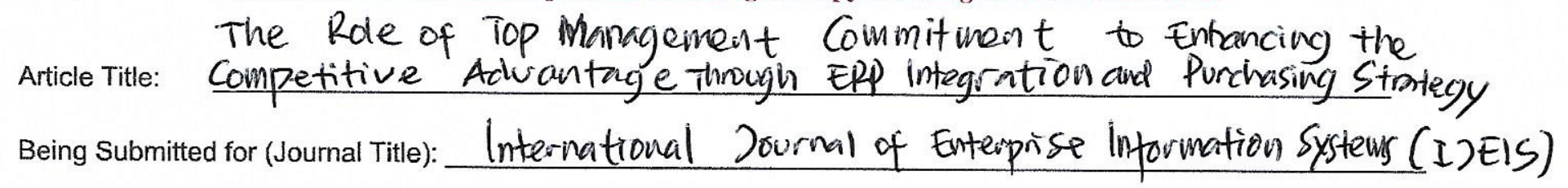

\section{Author's Warranty}

The author(s) hereby warrants that the manuscript named above that has been submitted to IGI Global for publication in the named book or any other IGI Global publication, IS ORIGINAL AND HAS NOT BEEN SUBMITTED FOR PUBLICATION OR PUBLISHED ELSEWHERE, and that all trademark use within the manuscript has been credited to its owner or written permission to use the name has been granted. In addition, the author(s) acknowledges that all images such as tables, screenshots, graphics, etc., do not have a copyright that is held by a third party. $\mid \mathrm{Gl}$ Global will not accept a manuscript for which the copyright is held by a third party. Authors may not use substantial verbatim text from another copyrighted work without the written permission of the copyright holder.

Author(s) understand that when submitting the final version of their accepted submission

- the file is submitted in Word format and the article is 5,000-8,000 words (approx. 15-25 pages)

- the text has been professionally copyedited, proofed and spellchecked by the author and is considered final and ready for publication without any further changes

- references and in-text citations are included and must follow strict APA style.

\section{Transfer of Copyright}

The author(s) in consideration of the publication of the above named manuscript also understands:

1. Author(s) agrees to, and does hereby assign all rights, title and interest, including copyrights, in and to the manuscript to Publisher. The author retains the rights to any intellectual property developed by the author and included in the manuscript including, without limitation, any models, theories, or conclusions formulated by the author. While the author may use any and all thoughts and research results developed or accumulated while working on a manuscript, and may rewrite, update, and re-title them for use in other publications, the author CANNOT use the verbatim text of the manuscript or any part thereof that has been copyrighted by IGI Global without first obtaining the written permission of IGI Global.

When the manuscript is ready for publication, it will be published at Publisher's own expense, under the Publisher's imprint or any other imprint the Publisher in its sole discretion elects.

2. Author(s) understand that no royalties or remuneration will be paid by the Publisher to the author for the above named submitted manuscript. Further, Author(s) acknowledge the manuscript is being provided on a volunteer basis for the professional recognition obtained by the publication.

3. The Author(s) will indemnify and defend Publisher against any claim, demand or recovery against Publisher by reason of any violation of any proprietary right or copyright, or because of any libelous or scandalous matter contained in the Manuscript.

4. Author(s) cannot post the contents of the article on any website or distribute the work to others in either electronic or print forms without the written permission of IG! Global. 
5. The Publisher will have the right to edit the work for the original edition and for any revision, provided that the meaning of the text is not materially altered. Publisher is solely responsible for the right to make all decisions on page layout and all other aspects of preparing the publication as they relate to suitability to the publisher's system, procedures, and business practices.

6. The Publisher will provide each Author with an electronic pdf file of Author's typeset manuscript as proof of publication.

7. When the Publisher decides that the public demand for this work no longer warrants its continued manufacture, the Publisher may discontinue manufacture and destroy any or all plates, books, and sheets without liability to the Author.

8. The Publisher may permit others to publish, broadcast, make recordings or mechanical renditions, publish book club and micro-film editions, make translations, and other electronic versions, quote, and otherwise utilize this work and material based on this work provided the author's name accompanies the work.

9. This Agreement, whenever called upon to be construed, shall be governed by the laws of the Commonwealth of Pennsylvania.

10. The parties to this Agreement consent and agree that all legal proceedings relating to the subject matter of this Agreement shall be maintained in the Court of Common Pleas of Dauphin County, Pennsylvania, or, if applicable, the United States District Court for the Middle District of Pennsylvania, and all parties hereto consent and agree that jurisdiction and venue for such proceedings shall lie exclusively within said Courts.

11. This Agreement represents the entire understanding between the parties hereto with respect to the subject matter hereof and this Agreement supersedes all previous representations, understandings of agreements, oral or written, between the parties with respect to subject matter hereof and cannot be modified except by a written instrument signed by the parties hereto.

12. This Agreement shall be binding upon and inure to the benefits of the parties hereto, their heirs, personal representatives, and, as permitted, assigns.

13. The Author or Lead Author (defined herein) represents and warrants to the Publisher, and the Publisher relies on such representations and warranties, that (select the applicable provision)

I am the sole author of this work submitted for publication

I am not the sole Author of the work submitted for publication but I have been designated by the other Authors as the Author who will assume overall responsibility for the work, serve as the managerial and corresponding author, and, if applicable, provide a significant contribution to drafting, reviewing and revising the work (the "Lead Author"). In designating me as Lead Author, all other Authors acknowledge and agree that on their behalf I have sole and complete authority to deal with the Publisher in all matters related to the work

I am neither the sole Author nor the Lead Author of the work submitted for publication. Each Author will sign this Agreement to evidence his or her consent to this Agreement.

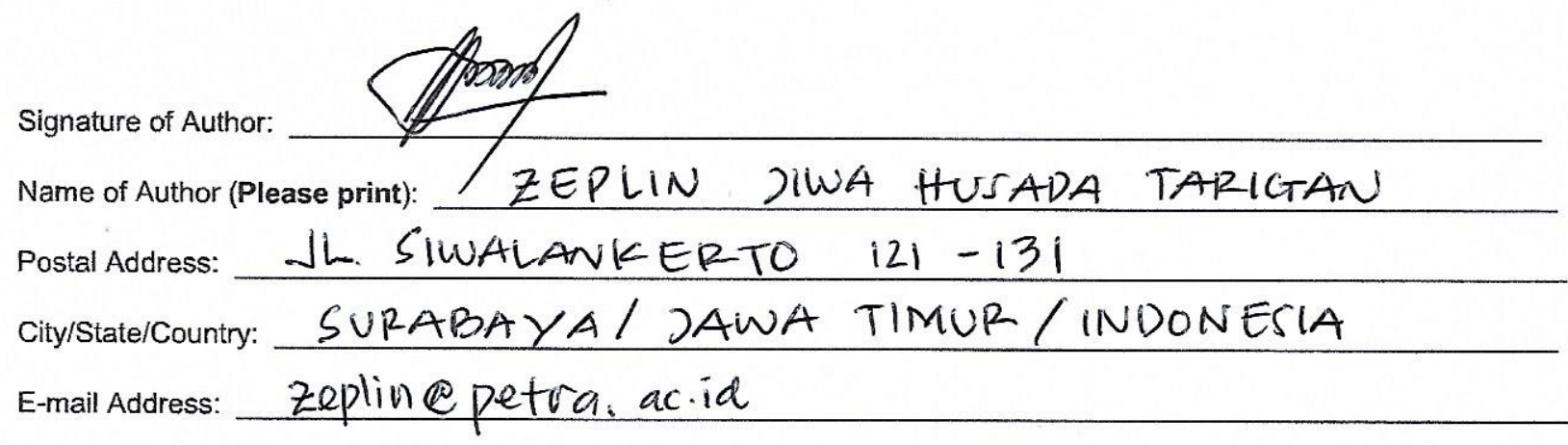


8. Madjid Tavana <tavana@lasalle.edu>

to me, Hotlan, Phd -

Dear authors: The review of your manuscript is completed. Your revised paper is now formally accepted for publication in IJEIS. Your paper is tentatively scheduled for publication Volume 4 this year (2019) or in Volume 1 next year (2020). Please allow 8 weeks for the preparation of the galley proofs.

....

布 